\title{
REPORTAŻE O KOŃCACH ŚWIATA. DAWNA GALICJA I BIAŁOSTOCCZYZNA WEDŁUG MARTINA POLLACKA I WŁODZIMIERZA PAWLUCZUKA ${ }^{1}$
}

\author{
ZBIGNIEW KOPEĆ ${ }^{2}$ \\ (Uniwersytet im. Adama Mickiewicza w Poznaniu)
}

Słowa kluczowe: reportaż, Cesarstwo Austro-Węgierskie, schyłek dziewiętnastowiecznego świata

Key words: reportage, Austro Hungarian Empire, the end of the nineteenth-century world, travel

\begin{abstract}
Abstrakt: Zbigniew Kopeć, REPORTAŻE O KOŃCACH ŚWIATA. DAWNA GALICJA I BIAŁOSTOCCZYZNA WEDŁUG MARTINA POLLACKA I WŁODZIMIERZA PAWLUCZUKA „PORÓWNANIA” 14, 2014, T. XIV, s. 151-160. ISSN 1733-165X. Praca jest próbą pokazania, jak dwa współczesne utwory nawiązujące do formuły gatunkowej reportażu przedstawiają schyłek dziewiętnastowiecznego świata doświadczanego przez mieszkańców wielonarodowego Cesarstwa Austro-Węgierskiego (Martin Pollack) lub też w jaki sposób z jego utratą radzą sobie zwykli ludzie mieszkający na wschodnich rubieżach imperium Romanowów. Pollack patrzy na mieszkańców dawnej Galicji z perspektywy wielokulturowości i cywilizacyjnego rozwoju. Włodzimierz Pawluczuk opisuje grupę związaną z Prorokiem Ilją w perspektywie religioznawczej i antropologicznej. Obaj autorzy pokazują światy, które musiały odejść w niebyt, ale Pawluczuk widzi w nich rezerwuar wartości duchowych.
\end{abstract}

Abstract: Zbigniew Kopeć, REPORTAGES ABOUT THE END OF THE WORLDS. OLD GALICIA AND BIAŁOSTOCCZYZNA ACCORDING MARTIN POLLACK AND WŁODZIMIERZ PAWLUCZUK. "PORÓWNANIA" 14, 2014, Vol. XIV, p. 151-160. ISSN 1733-165X. The article is an attempt of showing how two contemporary works which refer to the form of reportage depict the late 19th century experience of the multinational Austro-Hungarian Empire (Pollack). On the other hand, it shows how this loss is experienced by regular people on the eastern edges of the

${ }^{1} \mathrm{~W}$ polu zainteresowań będą dwa współczesne utwory: Po Galicji. O chasydach, Hucułach, Polakach i Rusinach. Imaginacyjna podróż po Galicji Wschodniej i Bukowinie, czyli wyprawa w świat, którego nie ma Martina Pollacka i Wierszalin. Reportaż o końcu świata Włodzimierza Pawluczuka.

${ }^{2}$ Correspondence Address: kzbsz@amu.edu.pl 
Romanov empire. Pollack takes a look at the inhabitants of former Galicia from a multicultural and civilisational development perspective. Pawluczuk describes the group formed around the prophet Ilja from the perspective of religious and anthropological studies. Both authors show worlds which had to go away, yet Pawluczuk sees it as a reservoir of spiritual values.

Michał Głowiński pisze, że tytuł utworu literackiego stanowi swoistą instrukcję obsługi jego lektury ${ }^{3}$. Instrukcja zawarta w książce Martina Pollacka pt. Po Galicji. O chasydach, Hucułach, Polakach $i$ Rusinach. Imaginacyjna podróż po Galicji Wschodniej i Bukowinie, czyli wyprawa w świat, którego nie ma jest instrukcją tylko pozornie jednoznaczną. Pozwala interpretować książkę jako przewodnik po wschodniej części nieistniejącej już monarchii austrowęgierskiej. Tak sugerować mógłby tytuł jej omówienia w internetowej witrynie kresy.pl, który brzmi: Pollack oprowadza po Galicji5. Na przewodnikowy charakter utworu wskazuje również jego kompozycja. Kolejne rozdziały dotyczą miast odwiedzanych zgodnie z porządkiem narzucanym przez marszrutę, jaką wyznacza kolej, rzecz jasna - cesarskokrólewska. W podobnym „przewodnikowym” porządku Galicję przedstawił autor licznych opracowań turystycznych - Mieczysław Orłowicz w roku 19146, a ponad dwadzieścia lat po nim, w roku 1936, Antoni Ossendowski . Można zatem przyznać rację Theodorowi Adorno, który w eseju z 1947 roku pisał o produkcie, jakim stała się turystyka i podróż: „To, co w przemyśle kulturowym pojawia się jako postęp, coś nieustannie nowego, co on oferuje, pozostaje osłoną czegoś zawsze jednakowego; wszędzie odmiana ukrywa szkielet, w którym mało się zmieniło"8. Martin Pollack, współczesny autor i tłumacz reportaży Kapuścińskiego, "sprzedaje” Galicję jako „produkt”, na który jest w Polsce duże zapotrzebowanie, zwłaszcza, że chodzi o Galicję dawną, z przełomu wieków XIX i XX, a więc z czasu, gdy nie istniały jeszcze wspomniane wyżej książki Orłowicza i Ossendowskiego.

Jest możliwa jednak druga, wcale nie konkurencyjna, a komplementarna interpretacja tytułu książki Martina Pollacka. Każe ona dostrzec w niej porządek nie

${ }^{3}$ M. Głowiński, Gatunek literacki i problemy poetyki historycznej. W: Genologia polska. Wybór tekstów. Red. E. Miodońska-Brookes, A. Kulawik, M. Tatara. Warszawa 1983.

${ }^{4}$ M. Pollack, Po Galicji. O chasydach, Hucułach, Polakach i Rusinach. Imaginacyjna podróż po Galicji Wschodniej i Bukowinie, czyli wyprawa w świat, którego nie ma. Przeł. A. Kopacki. Wołowiec 2007.

${ }^{5} \mathrm{http}: / /$ www.kresy.pl/publicystyka,omowienia?zobacz/pollack-oprowadza-po-galicji-1 (data dostępu: 28 IV 2013).

${ }^{6}$ M. Orłowicz, Ilustrowany przewodnik po Galicyi, Bukowinie, Spiżu, Orawie i Ślasku Cieszyńskim, z mapa Galicyi i 250 ilustracyami. Lwów 1914.

${ }^{7}$ A. Ossendowski, Huculszczyzna. Gorgany i Czarnohora. Poznań 1936.

8 Th. Adorno, Podsumowanie rozważań na temat przemystu kulturowego. W: Sztuka i sztuki. Przeł. K. Sauerland. Warszawa 1990, s. 13. 
tyle przestrzenny, ile czasowy, widzieć nie miejsca na mapie fizycznej, a czarne i białe dziury na mapie mentalnej Austriaków (i Polaków). Użyte w tytule "po" oznaczałoby pewien porządek chronologiczny. Do enumeracji sporządzonej $\mathrm{w}$ innym miejscu przez Ewę Wiegandt: po strukturalizmie, po komunizmie, po modernizmie9, dodać by należało zatem jeszcze jedno „po” - po Galicji.

Problematykę genologiczną książki Pollacka pomaga rozwiązać sugestia zawarta w dołączonej do książki recenzji, czy raczej rekomendacji napisanej przez Ryszarda Kapuścińskiego, która pozwala czytać ją jak reportaż. Wbrew pozorom, formuła gatunkowa książki Włodzimierza Pawluczuka: Wierszalin. Reportaż o końcu świata ${ }^{10}$ wcale nie jest łatwiejsza do określenia. Tym bardziej, że drugie wydanie książki opatrzono rozbudowanym tytułem zawierającym dodatkową informację trzydzieści lat później11, a jej autor znany jest przede wszystkim jako ceniony uniwersytecki profesor, socjolog, religioznawca i badacz kultury ludowej.

Podróż Martina Pollacka jest, jak sam autor przyznaje, podróżą imaginacyjną, co jednak nie oznacza, że jest to wyprawa, która się odbywa tylko siłą wyobraźni. Dochodzi do skutku głównie dzięki sumiennej pracy $\mathrm{w}$ bibliotece, szperaniu wśród stosów wiekowych gazet, broszur, ulotek. Książkę, przeznaczoną przede wszystkim dla austriackiego czytelnika, można wpisać w nurt, określany przez Huberta Orłowskiego jako „odpominanie"12. Do jej lektury zachęcić mają słowa: „Komu znana jest jeszcze dzisiaj Galicja? Kto wie, gdzie ona leży - a może inaczej, gdzie ona leżała? Bo przecież Galicji już dzisiaj nie ma. Ona zniknęła z mapy. Jej wschodnia część należy dzisiaj do Polski, a wschodnia do Ukrainy"13.

Polski czytelnik nie musi mieć takiego kłopotu poznawczego. O Galicji przypominają mu utwory wpisujące się $\mathrm{w}$ nurt prozy określany jako "proza południa"14, składające się na korpus tekstów współtworzących mit Austrii szczęśliwej, Austrii Felix, który można odnaleźć choćby w prozie Brunona Schulza, Stanisława Vincenza czy Andrzeja Kuśniewicza ${ }^{15}$.

Martin Pollack po części demitologizuje ten arkadyjski obraz. Nie pokazuje Galicji tylko jako arkadii, ani tylko w ten sposób, w jaki widział ją Karol Józef, bohater powieści Josepha Rotha, pt. Marsz Radetzky'ego doświadczający "galicyjskości" w jej fazie schyłkowej, gdzieś na pograniczu rosyjskim, gdzie jedyną rozrywkę

${ }^{9} \mathrm{E}$. Wiegandt, „po". W: Z perspektywy końca wieku. Studia o literaturze i jej kontekstach. Red. J. Abramowska, A. Brodzka. Poznań 1997.

${ }^{10}$ W. Pawluczuk, Wierszalin. Reportaż o końcu świata. Warszawa 1983.

${ }^{11}$ W. Pawluczuk, Wierszalin. Reportaż o końcu świata trzydzieści lat później. Białystok 1999.

${ }^{12} \mathrm{H}$. Orłowski, Warmia z oddali. Odpominanie. Olsztyn 2000.

${ }^{13}$ Zob. http://www.amazon.de/Galizien-verschwundene-Ostgaliziens-Bukowina-taschenbuch/dp/ 3458344470 (data dostępu: 22 IV 2013).

${ }^{14}$ M. Głowiński, Ewolucja polskiej prozy narracyjnej w XX wieku. „Nurt” 1974, nr 12.

${ }^{15}$ Robi to w fundamentalnej monografii Ewa Wiegandtowa. Zob. E. Wiegandt, Austria Felix, czyli o micie Galicji w polskiej prozie wspótczesnej. Poznań 1997. 
stanowi alkohol i hazard ${ }^{16}$, ale przestawia również galicyjską rzeczywistość z perspektywy warstw prostych, biednych ludzi.

Włodzimierz Pawluczuk jest w o wiele lepszej sytuacji. Również ma możliwość dotarcia do dokumentów źródłowych, ale dodatkowo może korzystać z metod charakterystycznych dla reportażu. Po pierwsze, wplata w swoją opowieść elementy autobiograficzne i autotematyczne. Po drugie, korzysta z możliwości, jakie dają wywiad i rozmowy ze świadkami. Do podobnych konwencji reporterskich odwoływał się wcześniej Józef Mackiewicz, kiedy w drugiej połowie lat trzydziestych przygotowywał dla wileńskiego "Słowa" reportażową serię o religijnych sektach rozsianych po północnowschodnich terenach międzywojennej Polski ${ }^{17}$. W przypadku Pawluczuka ma to tę dodatkową zaletę, że umożliwia bezpośredni kontakt ze współczesnymi ludźmi, którzy byli niegdyś powiernikami proroka Ilji i w chwili pisania książki prowadzą życie „najnormalniejszych” mieszkańców wsi z północnowschodniej, „powojennej” Polski, a w gruncie rzeczy czekają jednak „na drugie” przyjście swojego mistrza.

Pawluczuk np. tak opisuje spotkanie z kobietą, która w latach trzydziestych w religijnym szale niszczyła krzyże, za co współwyznawcy „zakuli ją w żelazną obręcz, łańcuchem przymocowali do ściany"18:

Chata jak chata - niska murszejąca, stodoła też wiekowa [...] Stara kobieta pośrodku gumna, kuśtykając na drewnianej protezie grabi rozwłóczone siano.

- Dzień dobry - zaczynam. [...]

- Chciałbym porozmawiać o Ilji.

- Jakim Ilji?

- No - o świętym....

- To idźcie do cerkwi... tam obrazy.... Batiuszka.

- Ale mnie chodzi o Ilję Grzybowskiego.... z Grzybowszczyzny.... Toż znaliście...

- Grzybowszczyzna? To gdzieś pod Krynkami.... Tam pytajcie.

I nagle odwraca się, grabie nieruchomieją na moment, ona zaś spojrzawszy badawczo, $\mathrm{z}$ napięciem, pyta krótko:

- A co zmartwychwstał?

- Nie - mówię - nie zmartwychwstał. [...]

Opuszcza głowę, grabi dalej, każdy ruch wymierzony: starannie zaczęty, starannie dokończony I znowu jakby mnie nie było"19.

Martin Pollack natomiast ogranicza się (przynajmniej pozornie) do obiektywnego opisu galicyjskiej rzeczywistości tylko z czasu, gdy wraz z nadchodzącym upadkiem monarchii Habsburgów miał przestać istnieć dziewiętnastowieczny ład

\footnotetext{
16 J. Roth, Marsz Radetzky'ego. Przeł. W. Kragen. Kraków 1995.

${ }_{17} \mathrm{~J}$. Mackiewicz, Bunt rojstów. Wilno 1938.

${ }_{18}$ W. Pawluczuk, Wierszalin. Reportaż o końcu świata..., s. 6.

${ }^{19}$ Ibidem, s. 5.
} 
świata. Temat ten podejmowano już wielokrotnie wcześniej. Np. Egon Naganowski pisał, komentując twórczość Roberta Musila: „rozkład i upadek państwa Habsburgów albo jego alegorycznych odbić, jest dla autorów paradygmatem postępującego w ciągu XX wieku rozkładu i upadku Europy, ba końca epoki w ogóle"20.

Według podobnych prawideł powody powstania religijnej sekty na grzybowszczyźnie interpretuje Pawluczuk, widząc ich przyczyny w krwawym, gwałtownym upadku monarchii i dynastii Romanowów oraz ich cesarstwa. W swojej książce pokazuje konsekwencje tego, że w latach trzydziestych żyjącym do niedawna $\mathrm{w}$ tradycyjnej gromadzie mieszkańcom wsi przychodzi się mierzyć z nowoczesnością reprezentowaną z jednej strony najpierw przez rewolucję, a potem bolszewickie państwo, a z drugiej - przez młodą, ambitną Polskę. Autor nie ogranicza się tylko do prezentacji faktów - jak zrobiłby może obiektywny „reporter”, ale opatruje je fachowym, socjologiczno-antropologicznym komentarzem: „Myśli o końcu świata nawiedzają z reguły ludzi, którzy są świadkami końca ich własnej kultury, będącej dla nich do niedawna absolutem [...]. Podobne kryzysy świadomości są udziałem całych grup kulturowych" - pisze ${ }^{21}$. Objawem tego kryzysu jest właśnie „zapotrzebowanie" na proroka Ilję, jego apostołów, pełnych religijnych uniesień kobiet, między które bez większych ograniczeń rozdzielono role matek potencjalnych zbawicieli. Pawluczuk nie widzi w tym chęci mistyfikacji, ale szczerą, autentyczną wiarę prostych polsko-białoruskich chłopów w to, że to właśnie oni muszą wziąć na swe barki zbawienie świata oraz zbudować w Wierszalinie Nowe Jeruzalem. Akcentując głęboką religijność członków sekty, zwraca równocześnie uwagę na ich pragmatyzm, wynikający z licznych zależności i postzależności. Nie czują raczej więzi z Polską, ale - jak mówi przekaz - wysyłają Piłsudskiemu worek pełen pieniędzy 22. Są prawosławni, ale to Kościołowi katolickiemu przekazują zbudowaną przez siebie cerkiew. Pomagają prawie każdemu, kto się podaje za cara, ponieważ pragną, by było "po staremu”, ale są też przekonani, że car, gdy wróci na tron, będzie o nich pamiętał.

Szukając wydarzeń, symptomów, które określałyby początek dwudziestego wieku, Marci Shore wskazuje na tendencje obecne w środkowoeuropejskich ruchach awangardowych (a które można było zauważyć również w rewolucji bolszewickiej), kosmopolityzm i internacjonalizm przedstawicieli świata sztuki i świata nauki, co przejawiało się chociażby np. w ich programowej nieomal wielojęzyczności ${ }^{23}$. Wszystko to w imię możliwości porzucenia "prowincjonalnych horyzontów narodowych oraz samej narodowości" - jak pisał w 1927 roku ideolog

${ }^{20}$ E. Naganowski, Podróż bez końca. O życiu i twórczości Roberta Musila. Kraków 1980, s. 278.

${ }^{21}$ W. Pawluczuk, Wierszalin. Reportaż o końcu świata..., op. cit., s. 7.

22 Ibidem, s. 88.

${ }^{23}$ M. Shore, Kosmopolityzm, awangarda i utracona naiwność Europy Środkowej. W: Nowoczesność jako źódło cierpień. Przeł. M. Sutowski. Warszawa 2012. 
czeskiej awangardy Karel Teige ${ }^{24}$. Zdaniem Shore kosmopolityzm ten nie byłby możliwy, gdyby nie wielonarodowość i wielojęzyczność monarchii austrowęgierskiej, która stanowiła żyzne podglebie dla modernizujących nurtów wieku XX w Europie. Pollack, odbywając swoją nie tyle imaginacyjną, ale biblioteczną podróż po Galicji, również wiele miejsca poświęca zjawisku wielojęzyczności Galicji. Odnotowuje, w jakich nakładach i w jakich językach ukazywały się w galicyjskich miastach gazety, książki, broszury. Jednak to, co w przypadku Shore jest, albo być ma, naukową hipotezą, w przypadku Pollacka stanowi również powtórzenie wcześniejszych przekonań, ugruntowanych m.in. w myśleniu mitycznym, które pozwala zobaczyć w Galicji krainę sprzed katastrofy, sprzed upadku wieży Babel. Pollack jak mantrę powtarza frazę, że żyli tam zgodnie Rusini, Polacy, Żydzi i Niemcy, pisze o polsko-rusińsko-żydowskich miasteczkach, o ulicach, przy których stały "polskie, niemieckie, żydowskie” sklepy ${ }^{25}$, w czym oczywiście słychać i echa polskiej „literatury południa”, i echo wspomnień Stefana Zweiga, odnoszące się raczej do elit towarzyskich i intelektualnych monarchii: „Europa umiała niegdyś cieszyć się beztrosko kalejdoskopową grą barw"26. Jednak gdy trzeba odpowiedzieć na pytanie, na ile narody zamieszkujące Galicję, mogły cywilizacyjnie zyskać na przynależności do monarchii, Pollack nie udziela jednoznacznej odpowiedzi. Przedstawiając Drohobycz jako jedno wielkie pole naftowe, wskazuje na szansę cywilizacyjnego rozwoju, ale podkreśla przede wszystkim olbrzymi wyzysk, jaki stał się udziałem setek, głównie żydowskich, robotników. Staje zdecydowanie po stronie Brunona Schulza, który w Sklepach cynamonowych z niedowierzaniem i niesmakiem patrzy na "nowoczesne" ulice swojego miasta. Opowiadanie pt. Ulica krokodyli jest jednym z koronnych przykładów kulturowego upadku, który Pollack przywołuje na prawach dokumentu. Prawdziwy koniec dziewiętnastowiecznego Drohobycza, czyli Drohobycza kupców kolonialnych i bławatnych, miał jednak nastąpić - pisze Pollack - kiedy w „Tygodniku Drohobyckim” ukazało się ogłoszenie, że „Maks Bartischan ma zaszczyt otworzyć przy rynku American House, magazyn nowości, czyli sklep z konfekcją, który będzie prowadził wszelkie towary, od rękawiczek, krawatów i kołnierzyków do >butów amerykańskich i karlsbadzkich<" 27.

Polski historyk ukraińsko-żydowskiego pochodzenia, Henryk Wereszycki, pisze:

w chwili rozpoczęcia ostatniej wojny Austro-Węgry przedstawiały kraj kwitnący zarówno w dziedzinie gospodarczej, jak i kulturalnej. Toteż kiedy po upadku tego wielonarodowego mocarstwa rozpoczęły na jego gruzach istnienie nowe państwa, mogło

\footnotetext{
${ }^{24}$ Cyt. za. M. Shore, Kosmopolityzm, awangarda i utracona naiwność Europy środkowej..., op. cit., s. 19. ${ }^{25}$ M. Pollack, Po Galicji. O chasydach, Hucułach, Polakach i Rusinach..., op. cit., s. 17. 26S. Zweig, Świat wczorajszy. Przeł. M. Wisłowska. Warszawa 1957, s. 158.

${ }^{27}$ M. Pollack, Po Galicji. O chasydach, Hucułach, Polakach i Rusinach..., op. cit., s. 53.
} 
powstać przekonanie wśród ludności, że panowanie austriackie to były te $>$ dawne, dobre czasy<, które przeszły w niepowrotną przeszłość 28 .

Pollack nie do końca zgadza się z takim rozpoznaniem. Po baumanowsku uznaje, że jedną z ważniejszych dla dwudziestego wieku opozycji jest opozycja czystość - brud, choć sam, jak mało kto, wie, do czego ona doprowadziła. Chętnie wskazuje na brud, chcąc w nim widzieć oznakę zapóźnienia cywilizacyjnego szerokich rzesz wielonarodowej galicyjskiej biedoty, która w poszukiwaniu chleba gotowa jest opuścić nieprzyjazną ziemię, by udać się do Ameryki²9.

Kazimierz Wyka, odmawiając większych wartości prozie Brunona Schulza, pisał w polemice ze Stefanem Napierskim: „Schulza obchodzą tylko istnienia marginesowe, zepchnięte na rubieże czasu; epos emerytury i dziwactw, narośle na pustym czasie". Dlatego też krytykuje

powoływanie się na śp. Franciszka Józefa, potężnego i złośliwego demiurga, na prowincję galicyjską, na wszystko co było emeryturą historii [...]. Postawmy emeryta jesienią we wschodniogalicyjskim miasteczku, gdzie nic się nie dzieje, zrozumiemy, że czas może stać się żywiołem metafizycznym i obsesją ${ }^{30}$.

Głos Kazimierza Wyki z jednej strony współbrzmi z oficjalną państwową propagandą, przedstawiającą „polską” cześć Galicji i wschodnią część byłego zaboru rosyjskiego ${ }^{31}$ jako obszar, na terenie którego bardzo szybko zachodzą procesy modernizacyjne, a z drugiej strony - z relacją Martina Pollacka, który ulega czasem stereotypom, ale jest daleki od wszelkiego sentymentalizmu i mitologizacji, próbując swój opis Galicji ograniczyć tylko do sfery gospodarczej i politycznej, w której nie ma miejsca na zaklęcia, baśnie, legendy i mityzacje rzeczywistości.

Przykładu, który doskonale to ilustruje, dostarcza postać Ołeksy Dobosza, należącego do legendarnych huculskich opryszków. Dla Martina Pollacka jest on bandytą uprzykrzającym życie spokojnym, pracowitym obywatelom austriackiego cesarstwa, ale np. dla Stanisława Vincenza - który poświęca temu bohaterowi obszerny rozdział Prawdy starowieku - jest romantycznym buntownikiem, którego zasłużona legenda nigdy nie zostanie zapomniana na huculszczyźnie ${ }^{32}$. Podobnie przedstawia opryszka w przywołanej wcześniej książce Antonii Ossendowski.

Właśnie na podobne „legendy” szczególnie jest wyczulony Pawluczuk, a fascynację historią chłopów ogarniętych szałem religijnych uniesień dodatkowo

${ }^{28}$ H. Wereszycki, Historia Austrii. Wrocław 1972, s. 301.

${ }^{29}$ Zob. kolejną książkę Pollacka pt. Cesarz Ameryki. Wielka Ucieczka z Galicji. Przeł. K. Niedenthal. Wołowiec 2012.

${ }^{30}$ K. Wyka, Dwugłos o Schulzu, „Ateneum” 1939, nr 1.

31 Zob. K. Pruszyński, Kiełkowanie na bagnie. W: Podróż po Polsc. Warszawa 1937; F. Ossendowski, Huculszczyzna. Gorgany i Czarnohora. Poznań 1936.

32S. Vincenz, Prawda starowieku. Obrazy, dumy i gawędy z Wierchowiny Huculskiej. Sejny 2002. 
podsyca przekonaniem, że czerpanie z niej może dla człowieka z drugiej połowy XX wieku oznaczać oczyszczający powrót do źródeł. Zainteresowanie Pawluczuka Wierszalinem wiąże się nie tylko z jego uniwersyteckimi pasjami, ale wpisuje się, kto wie, czy nie przede wszystkim, w obszar wyznaczony przez polski wariant kontrkultury we wszystkich obecnych jej nurtach: przełamaniu monopolu teorii w naukach społecznych, poszukiwaniu podstaw dla nowej koncepcji człowieka w filozofii i religiach Dalekiego Wschodu, przekonaniu o ważkości refleksji nad stosunkiem człowieka do przyrody i przebudzeniu „świadomości ekologicznej”33.

Wierszalin - wieś znajdująca się w północnowschodniej Polsce - i spotykani po latach wyznawcy proroka Eliasza wraz z otaczającą ich mistyczną legendą doskonale nadawali się przecież na "obiekty" poszukiwań kontrkulturowych. Zdawał sobie z tego chyba sprawę Pawluczuk, "pokazując” Wierszalin Jerzemu Grotowskiemu, Włodzimierzowi Staniewskiemu, twórcy podlubelskiego teatru w Gardzienicach, czy inspirując związanych z teatrem Wierszalin Tadeusza Słobodzianka i Piotra Tomaszczuka do stworzenia spektakli poświęconych Ilji Grzybowskiemu. Chcąc nie chcąc, stworzył mit Wierszalina. Najważniejszym bohaterem Reportażu o końcu świata... jest jednak Jerzy Grotowski - jedna z głównych postaci polskiej kontrkultury, do której dziedzictwa przyznaje się dziś wielu artystów. O ważności tej postaci $\mathrm{w}$ Polsce $\mathrm{i}$ funkcjonowaniu $\mathrm{w}$ różnych rejestrach kultury doskonale świadczy choćby fakt, że stała się ona wielkim, ale nieobecnym bohaterem "obrachunkowej” powieści Bronisława Wildsteina, pt. Mistrz ${ }^{34}$, której akcja rozgrywa się w posttransformacyjnej Polsce.

Swoje współczesne kontakty z Wierszalinem Pawluczuk proponuje rozpatrywać $w$ perspektywie antropologii drogi. Chcąc dotrzeć do związanych z nim ludzi, odbywa pieszą, wyczerpującą wędrówkę. Nagrodą są rozmowy z wyznawcami Ilji i wspólne śpiewanie hymnów ułożonych na cześć proroka przed półwieczem. Modele takich podróży sięgają do tradycji Jana Jakuba Rousseau i literatury utopijnej. W wieku XX podobne wyprawy odbywał Carlos Castaneda i sam Jerzy Grotowski. Tendencje obecne w kontrkulturze były głównym motorem, który kazał Pawluczukowi poszukiwać „prawdy” u prostych ludzi, niegdyś ogarniętych religijnym szałem, by zbawiać świat w chwili, gdy ścierały się jeszcze żywa pamięć o dawnym imperium i o zasiadającym na tronie carze z wpływami nowego, ambitnego państwa, propagującego swój wzorzec nowoczesności. Tą samą drogą poszli potem twórcy kontrkulturowych teatrów. Pollack, by dotrzeć do Galicji, nie musi wychodzić z biblioteki, bo właśnie w niej znajduje wszelkie potrzebne informacje. Upraszczając, powiedzieć można, że różnica między nimi jest taka, jak miedzy Carlosem Castanedą a Claude Lévi-Straussem. Pierwszy bierze

${ }^{3}$ Zob. A. Jawłowska, Wolność w systemie zniewolenia. Rozmowy o polskiej kontrkulturze. Warszawa 2008, s. 22-45.

${ }^{34}$ Zob. B. Wildstein, Mistrz. Warszawa 2004. 
do ręki wędrowny kij, by dotrzeć do ludzi, którzy pokażą mu, jak można osiągnąć duchową przemianę, drugi - mógłby podpisać się pod słowami autora Smutku tropików, negującego konieczność poznania empirycznego. Nie warto - twierdził Levi-Strauss - ulegać „frazesom i banałom przemienionym cudem w rewelacje z tego tylko powodu, że ich autor zamiast siedzieć i pisać na miejscu, uświęci je przebywszy 20000 kilometrów" 35 .

Trudno, rzecz jasna, orzec, która konwencja ostatecznie okazuje się bardziej przydatna, jako wehikuł specyficznego rodzaju nostalgii. Obaj autorzy mówią w gruncie rzeczy o tym samym: o tym, że ludzie żyjący pod koniec dwudziestego i na początku dwudziestego pierwszego wieku chcą wciąż doświadczać końca wieku dziewiętnastego i związanego z nim świata, nawet, jeśli jest to świat w fazie schyłkowej.

\section{Bibliografia}

Adorno Th., Podsumowanie rozważań na temat przemystu kulturowego. W: Sztuka i sztuki. Przeł. K. Sauerland. Warszawa 1990, s. 13.

Głowiński M., Ewolucja polskiej prozy narracyjnej w XX wieku. „Nurt” 1974, nr 12.

Głowiński M., Gatunek literacki i problemy poetyki historycznej. W: Genologia polska. Wybór tekstów. Red. E. Miodońska-Brookes, A. Kulawik, M. Tatara. Warszawa 1983.

Jawłowska A., Wolność w systemie zniewolenia. Rozmowy o polskiej kontrkulturze. Warszawa 2008.

Levi-Strauss C., Smutek tropików. Przeł. A. Steinsberg, Warszawa 1966.

Mackiewicz J., Bunt rojstów. Wilno 1938.

Naganowski W., Podróż bez końca. O życiu i twórczości Roberta Musila. Kraków 1980, s. 278.

Orłowicz M., Ilustrowany przewodnik po Galicyi, Bukowinie, Spiżu, Orawie i Śląsku Cieszyńskim, z mapa Galicyi i 250 ilustracyami. Lwów 1914.

Orłowski H., Warmia z oddali. Odpominanie. Olsztyn 2000.Witryna internetowa: http://www.amazon. de/Galizien-verschwundene-Ostgaliziens-Bukowina-taschenbuch/dp/3458344470 (data dostępu: 28 IV 2013).

Ossendowski F. A. , Huculszczyzna. Gorgany i Czarnohora. Poznań 1936.

Pawluczuk W., Wierszalin. Reportaż o końcu świata trzydzieści lat później. Białystok 1999.

Pawluczuk W., Wierszalin. Reportaż o końcu świata. Warszawa 1983.

Pollack M. , Po Galicji. O chasydach, Hucułach, Polakach i Rusinach. Imaginacyjna podróż po Galicji Wschodniej i Bukowinie, czyli wyprawa w świat, którego nie ma. Przeł. A. Kapacki. Czarne 2007.

Pollack M., Cesarz Ameryki. Wielka Ucieczka z Galicji. Przeł. K. Niedenthal. Czarne 2012.

Pruszyński K., Kietkowanie na bagnie. W: Podróż po Polsce, Warszawa 1937.

Roth J., Marsz Radetzy'ego. Przeł. W. Kragen. Kraków 1995.

Shore M., Kosmopolityzm, awangarda i utracona naiwność Europy środkowej, w: Nowoczesność jako źródło cierpień. Przeł. M. Sutowski. Warszawa 2012.

Vincenz S., Prawda starowieku. Obrazy, dumy i gawędy z Wierchowiny Huculskiej. Sejny 2002.

Wereszycki H., Historia Austrii. Wrocław 1972, s. 301.

${ }^{35}$ C. Levi-Strauss, Smutek tropików. Przeł. A. Steinsberg. Warszawa 1966, s. 10. 
Wiegandt E., "po", w: Z perspektywy końca wieku. Studia o literaturze i jej kontekstach. Red. J. Abramowska, A. Brodzka. Poznań 1997.

Wiegnadt E., Austria Felix, czyli o micie Galicji w polskiej prozie wspótczesnej. Poznań 1997.

Wildstein B., Mistrz. Warszawa 2004.

Witryna internetowa: http:/ / www.kresy.pl/publicystyka,omowienia?zobacz/pollack-oprowadza-pogalicji-1 (data dostępu: 28 IV 2013).

Wyka K., Dwugłos o Schulzu. „Ateneum” 1939, nr 1.

Zweig S., Świat wczorajszy. Przeł. M. Wisłowska. Warszawa 1957, s. 158. 